\title{
A Case of Primary Intestinal Lymphangiectasia Diagnosed by Double Balloon Enteroscopy
}

\author{
Jung Min Lee, Jong Bum Kim, Seung Wook Bak, Bong Kyu Lee, Nam Hun Lee, Young Ho Seo \\ Department of Internal Medicine, Gwangju Veterans Hospital, Gwangju, Korea
}

Primary intestinal lymphangiectasia is a congenital lymphatic disorder characterized by dilated intestinal lacteals resulting in lymph leakage into the small bowel lumen and responsible for protein losing enteropathy. As a result, generalized edema, hypoalbuminemia, and lymphocytopenia are clinically manifested. We could not find the reason by several examinations. Therefore, we performed double balloon enteroscopy (DBE), and intestnal lymphangiectasia was diagnosed histologically by a biopsy. DBE is a safe and effective method to diagnose small bowel lymphangiectasia. We report a case of primary intestinal lymphangiectasia, which occurred in a 54-year-old male patient with generalized edema and ascites. (Intest Res 2013;11:6670)

Key Words: Intestinal lymphangiectasia; Double balloon enteroscopy

\section{서 론}

장림프관확장증은 장점막의 확장된 림프관을 통해 유미(chyle)가 장내로 유출되는 것을 특징으로 하는 질환이다. 주증상으로 설사, 오 심, 구토, 부종 둥이 동반되며 저단백혈증으로 인해 유미성 복수, 전신 부종, 늑막삼출 등이 생길 수 있다.

1959년 Gordon'이 시험적 개복술을 통해 관찰한 림프관 이상을 기 술하였고, 1961년 Waldmann 등이 소장생검에서 림프관의 이상을 발 견하고 단백질 소실을 일으키는 장 질환으로 원발장림프관확장증이 란 용어를 처음 보고한 이후 현재까지 국내에서도 몇몇 보고가 있어 왔다.

저자들은 전신부종, 저알부민혈증, 복수를 주소로 내원한 성인 환 자에서 alpha 1-antitrypsin 청소율을 측정하여 장 단백질 소실을 발견 하였고, 이중풍선 소장내시경을 통한 조직검사로 확진된 십이지장과 소장을 동시에 침범한 원발장림프관확장증 1예를 경험하였기에 보고 하는 바이다.

Received September 10, 2012. Revised November 11, 2012.

Accepted December 13, 2012.

Correspondence to Jung Min Lee, Department of Internal Medicine,

Gwangju Bohun Hospital, 99 Cheomdanwolbong-ro, Gwangsan-gu, Gwangju

506-705, Korea. Tel: +82-62-602-6383, Fax: +82-62-602-6988, E-mail:

jminlee75@nate.com
증 례

54세 남자 환자는 수년 전부터 악화와 호전을 반복하는 하지 부종이 있었으며, 최근 증상이 악화되어 타 병원에서 시행한 혈액 검사 결과 저알부민혈증을 보이고 소장조영술 검사에서 소장 점 막 주름의 비후가 있어 소장내시경을 위해 본원으로 전원되었 다. 과거력 및 가족력에서 특이소견은 없었다. 신체검사에서 신 장 $164 \mathrm{~cm}$, 체중 $62 \mathrm{~kg}$, 혈압 110/70 mmHg, 맥박수 80회/분, 호 흡수 18 회/분, 체온 $36.5^{\circ} \mathrm{C}$ 였다. 전신 상태는 만성 병색을 보였 으며, 흉곽은 함몰없이 대칭적이었고 간, 비장 등은 촉지되지 않 았다. 복부는 팽만, 이동탁음, 경한 함요 부종 소견을 보였고, 하 지의 함요 부종도 관찰되었다. 신경학적 소견은 정상이었다. 양 쪽 폐음은 깨끗하였고 심음은 규칙적이었으며 심잡음은 들리지 않 았다. 혈액검사에서 백혈구수 $6,000 / \mathrm{mm}^{3}$, 림프구수 $1,100 / \mu \mathrm{L}$ (18.5\%), 혈색소 $11.9 \mathrm{~g} / \mathrm{dL}$, 헤마토크릿 $35.2 \%$, 혈소판 $374,000 /$ $\mathrm{mm}^{3}$, 생화학검사에서 총 단백 $3.4 \mathrm{~g} / \mathrm{dL}$, 알부민 $2.3 \mathrm{~g} / \mathrm{dL}$, 총 빌리 루빈 $0.1 \mathrm{mg} / \mathrm{dL}, \mathrm{AST} / \mathrm{ALT}$ 26/30 IU/L, alkaline phosphatase $/ \gamma$ GT $38 / 6$ IU/L, BUN/creatinine $25.8 / 1.0 \mathrm{mg} / \mathrm{dL}$, 칼슘 $8.2 \mathrm{mg} /$ $\mathrm{dL}$, 인 $3.1 \mathrm{mg} / \mathrm{dL}$, 마그네슘 $2.3 \mathrm{mg} / \mathrm{dL}$, 나트륨/칼륨 $142 / 4.5$ $\mathrm{mEq} / \mathrm{L}, \mathrm{PT} / \mathrm{PTT} 13.0$ (international normalized ratio 1.02)/35.1 초, triglyceride $64 \mathrm{mg} / \mathrm{dL}$, cholesterol $100 \mathrm{mg} / \mathrm{dL}$ 이었다. 요단백 및 신기능검사, 대변내 기생충 검사, 혈청 면역글로불린치는 모두 정상 범위였다. 상부위장관내시경검사, 대장내시경검사에서 특이소견 없

๑ Copyright 2013. Korean Association for the Study of Intestinal Diseases. All rights reserved.

This is an Open Access article distributed under the terms of the Creative Commons Attribution Non-Commercial License (http://creativecommons.org/licenses/by-nc/3.0)

which permits unrestricted non-commercial use, distribution, and reproduction in any medium, provided the original work is properly cited. 
었다. 복수천자검사에서 복수의 triglyceride $1,181 \mathrm{mg} / \mathrm{dL}$, adenosine deaminase $10.0 \mathrm{U} / \mathrm{L}$, 적혈구 $150 / \mathrm{mm}^{3}$, 백혈구 $380 / \mathrm{mm}^{3}$ (림프구 $39 \%$ )였고, 색깔은 탁하고 우윳빛이었다(Fig. 1). 심전도 검사는 정상 소견이었다. 흥부 방사선 촬영에서는 심장비대와 폐울혈 소견은 없었 다. 복부 컴퓨터단층촬영검사에서 복수와 소장의 미만성 확장 소견이 있었으나 복강내 종괴나 림프절 종대는 관찰되지 않았다(Fig. 2). 심 장 초음파검사에서 이상 소견은 보이지 않았다. 이중풍선 소장내시경 검사에서 십이지장과 공장, 회장부 점막에서 하얀 미세결절성 변화를 보이며 조직검사 시 유백색 액체가 흘러나오는 것을 관찰할 수 있었 고(Fig. 3), 점막층에서 림프관 확장이 관찰되었다(Fig. 4). 장림프관 확장증이 의심되어 실시한 24시간 대변 alpha 1-antitrypsin clearance 검사에서 $202.1 \mathrm{~mL} / \mathrm{day}$ 로 증가되어 있었고, ${ }^{99 \mathrm{~m}} \mathrm{Tc}$-phytate 림프스캔 에서 양측 서혜부 림프절의 비대 소견이 있었으나 측부 림프 순환이나 비정상적인 림프 유출 소견은 없었다(Fig. 5). 이 환자는 원발장림프 관확장증으로 진단하였고, 고단백 식이, 중쇄 중성지방을 위주로 하

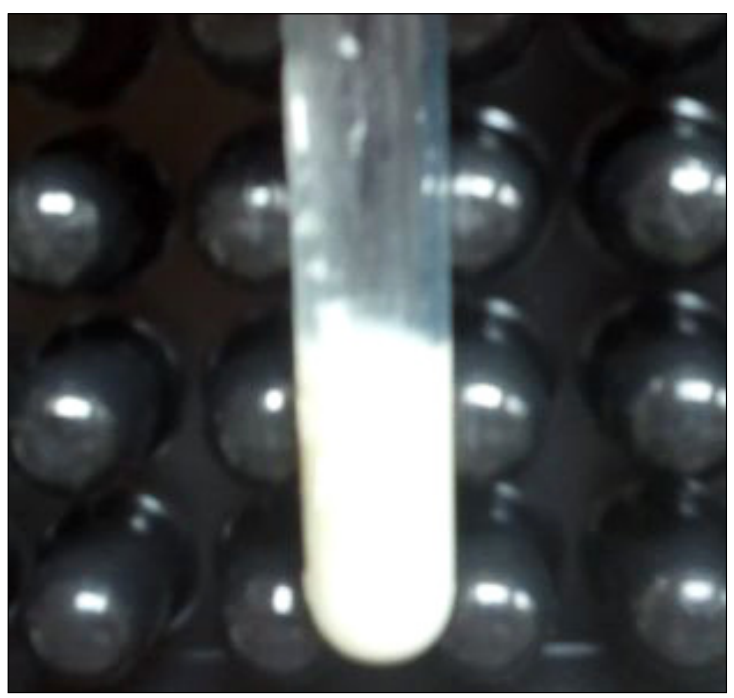

Fig. 1. Gross finding of ascitic fluid. Ascitic fluid shows milky and turbid appearance.
는 저지방식이, 알부민 투여, 경구용 분지쇄 아미노산 제제, furosemide $40 \mathrm{mg} /$ day, spironolactone $50 \mathrm{mg} /$ day 등으로 치료하였으며, 복수, 부종 및 생화학검사에서 총 단백 $4.6 \mathrm{~g} / \mathrm{dL}$, 알부민 $3.0 \mathrm{~g} / \mathrm{dL}$ 로 호전을 보여 현재 외래 추적 관찰 중이다.

\section{고 찰}

장림프관확장증은 소장의 점막고유층 및 점막하층에서 일어나는 림프관의 초점성 또는 미만성 확장으로 혈청 단백질과 림프구가 장내 로 누출되면서 단백질소실장병증, 저알부민혈증, 저단백성 부종, 림 프구감소증을 특징으로 하는 질환이다. 그 원인이 원발성인지 이차 성인지를 감별하는 것이 중요하다. 원발성은 소아와 젊은 성인에서 주로 발생하고 선천적인 림프계의 이상과 폐쇄가 원인이며, 가족력 이 있는 예도 보고되고 있다. ${ }^{3}$ 단독 병변일 수도 있으나 Noonan 혹은

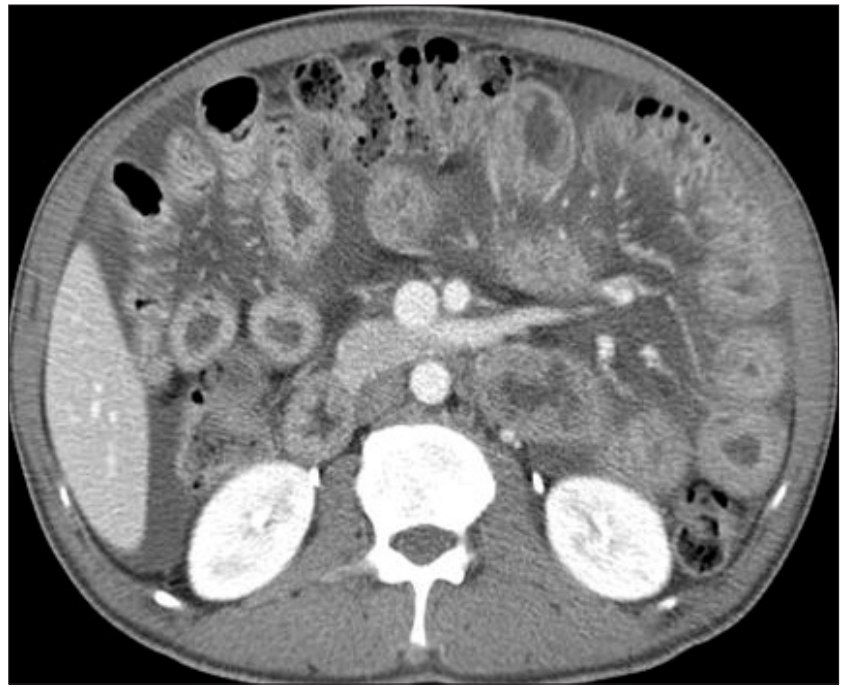

Fig. 2. Abdominal CT finding. Abdominal CT shows diffuse wall thickening of bowel loops with ascites, but abdominal mass or lymphadenopathy is not seen.
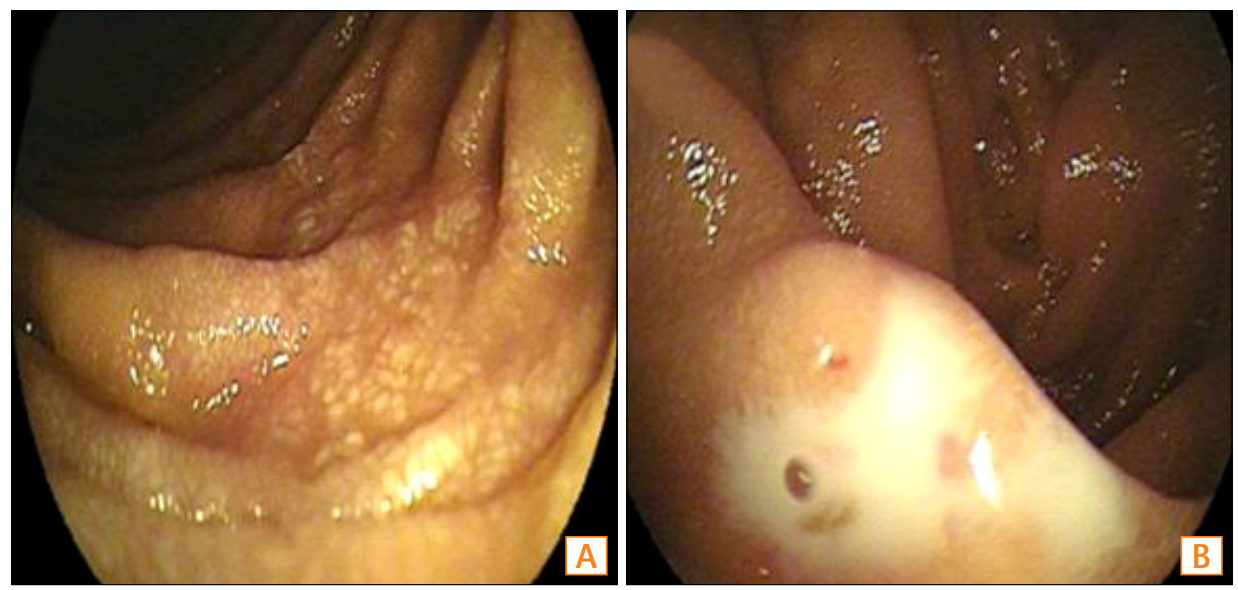

Fig. 3. Double-balloon enteroscopic findings. (A) Multiple scattered white plaques were noted on the jejunum. (B) It showed a milky fluid oozing from the jejunal mucosa after biopsies. 

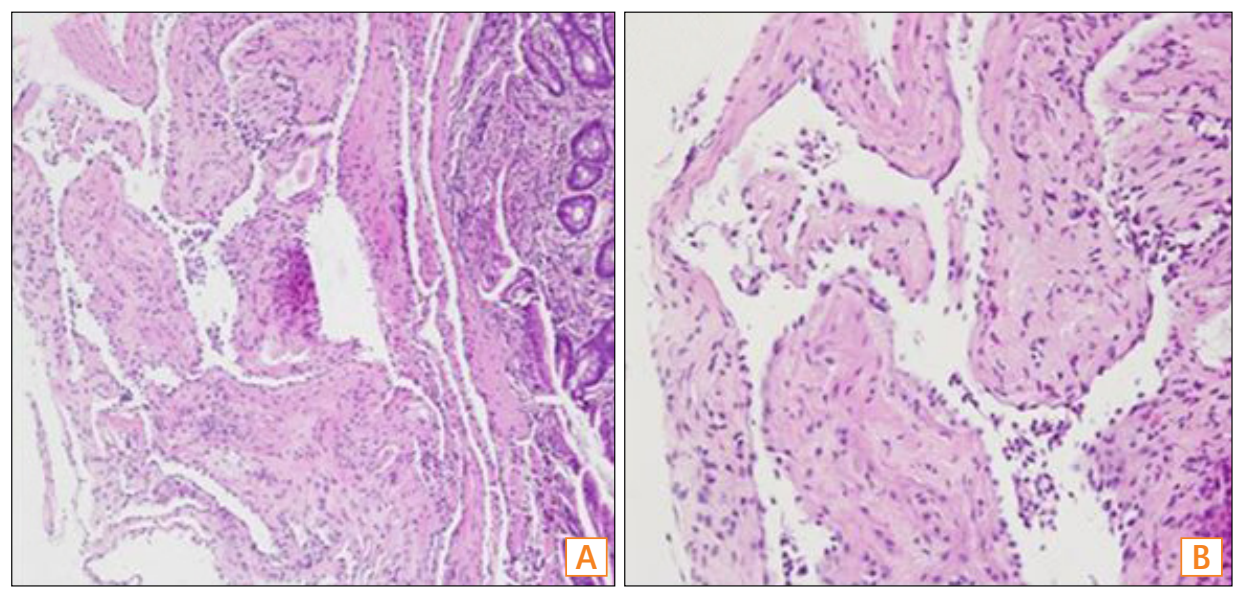

Fig. 4. Pathologic findings. Diffuse dilatations of the mucosal lymphatic ducts were observed (HEtE stain; A: ×100, B: ×200).

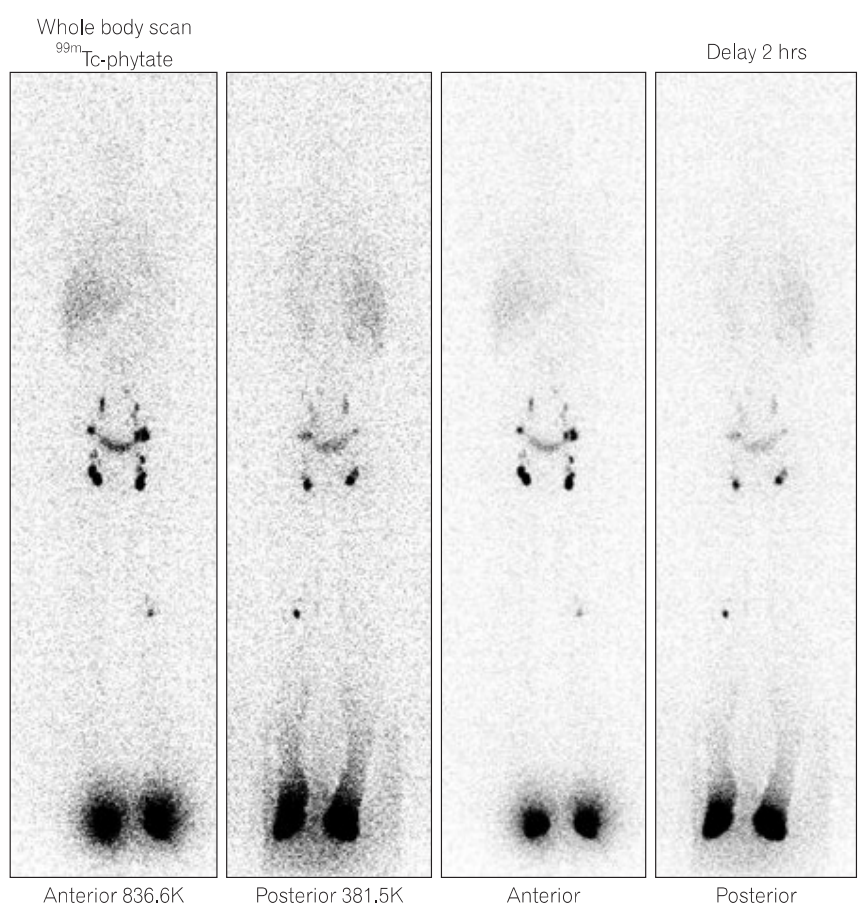

Fig. 5. ${ }^{99 m}$ Tc-phytate lymphoscintigraphy. Lymphoscintigraphy shows both inguinal lymph node hyperplasia without collateral lymphatic flow and accumulation of tracers in the peritoneal cavity.

Klippel-Trenaunay-Weber 증후군 같은 전신성 질환의 한 증상일 수 도 있다. 이차적인 경우에는 선행 병변으로 장회전이상, 협착심장막 염, 크론병, 장간막 결핵 또는 사르코이드증, 좌측 쇄골하 정맥압을 높이는 우심부전 등이 대표적이다. 선행 질환의 발병 시기에 따라 다 양한 연령층에서 발병될 수 있으나 성인에서 주로 발병하며, 정상적인 면역글로불린, 항핵항체 양성 및 생검 조직의 다양한 염증성 소견을 보이는 등의 임상적 특징이 있다. ${ }^{3,4}$ 이번 증례는 성인 연령에서 발병되 었으나 심장 초음파, 복부 컴퓨터단층촬영, 림프스캔, 소장조영술, 상 부위장관내시경검사, 대장내시경검사, 이중풍선 소장내시경검사 등 으로 이차성 질환을 배제할 수 있으며, 항핵항체 음성, 생검에서 염증
이 없는 소견으로 원발장림프관확장증으로 진단되었다.

장림프관확장증 환자들은 알부민 소실과 함께 흔히 림프액 상실로 인한 면역글로불린과 순환림프구의 감소가 동반된다. 반감기가 짧은 단백질(인슐린, $\mathrm{IgE}$ 등)은 상대적으로 정상에 가까운 혈중농도를 유 지하지만, 반감기가 긴 단백질(알부민, $\mathrm{IgG}$ ) 혈중 농도는 현저히 감소 하게 된다. 이번 증례에서는 이와 부합되지 않게 면역글로불린이 정 상수치였으며 이는 유미 복수로 인한 복부 염증과 정상적인 절대 림 프구수를 유지하기 위한 B 림프구 보상적 증가가 영향을 받은 것으 로 추정할 수 있다. ${ }^{5}$

나이에 맞지 않은 부종과 함께 저알부민혈증이 있는 환자에서 신 질환, 간질환 및 영양 부전, 흡수장애 병력이나 검사 소견이 보이지 않 고 저림프구증이 동반되어 있는 경우에는 장관내 단백질소실 질환에 의한 저단백혈증을 의심하여야 한다. ${ }^{6}$ 원발장림프관확장증의 진단은 내시경을 이용한 특징적인 소견과 소장의 점막조직 검사로 비정상적 으로 확장된 림프관과 동위원소를 이용하여 장관내로의 단백질소실 을 증명하고 다른 기저 질환이 없다는 것을 증명해야 한다.

과거에는 장관 단백질소실의 진단을 위해 동위원소를 이용하였고, ${ }^{61} \mathrm{Cr}$ 알부민, ${ }^{131} \mathrm{I}$ 알부민 등이 일반적으로 이용되어 왔다. 수일간 대변 을 모아 대변으로 배설된 방사성 동위원소의 양을 측정하는 방법을 사용했으나, ${ }^{7}$ 상대적으로 비싸고 오랫동안 대변을 모아야 하는 불편 함 등으로 현재는 잘 사용되지 않는다. 근래에는 24시간 대변 alpha 1-antitrypsin 청소율과 ${ }^{99 \mathrm{~m}} \mathrm{Tc}$ 인혈청알부민(human serum albumin) 스캔이 많이 사용되고 있다. 내인성 단백질인 alpha 1-antitrypsin은 분자량이 알부민과 비슷하면서 분비, 재흡수가 없고 분해되지 않은 상태로 대변으로 배출되기 때문에 장관내 알부민 소실을 비교적 정확 하게 반영하며 청소율(clearance)을 구하는 방법이 표준 방법이지만, 수일간 대변을 모으기가 어려우며 대변 내 농도를 측정하는 것 또한 쉽지 않다. 민감도와 특이도는 각각 $93.3 \%$ 및 $90 \%$ 로 보고된 바 있 다. 우리나라에서 보고한 정상인의 수치는 $15 \pm 3 \mathrm{~mL} / \mathrm{day}$ 이며 외국 과 비슷하다. ${ }^{8}$ Alpha 1-antitrypsin 청소율과 혈청 알부민과는 유의한 관계이지만 직선적 상관 관계는 미약하다. 각종 위장관 단백질소실이 있는 소화기 질환의 선별검사와 치료효과 판정에 유용하지만 정량검 사로서의 가치는 떨어진다. ${ }^{8}$ 실제로 혈청 알부민이 $3.0 \mathrm{~g} / \mathrm{dL}$ 미만으 
로 떨어지면 alpha 1-antitrypsin 청소율은 $180 \mathrm{~mL} /$ day를 초과한다. ${ }^{9}$ 이번 증례에서는 혈청 알부민은 $2.3 \mathrm{~g} / \mathrm{dL}$ 로 감소되어 있었고 alpha 1-antitrypsin 청소율은 $202.1 \mathrm{~mL} /$ day로 정상치보다 현저하게 증가 되어 있어 장관의 혈장단백질소실을 확인할 수 있었다.

$\mathrm{Ko}$ 와 $\mathrm{Seo}^{10}$ 는 원발장림프관확장증 환자에서 림프스캔의 민감도 가 $31 \%$ 로 다른 검사에 비해 떨어지는 편이었으나 장 이외에도 사지 의 림프관의 이상을 발견할 수 있다고 하였으며, So 등믄 장림프관 확장증 환자에서 ${ }^{99 \mathrm{~m}} \mathrm{Tc}$-antimony sulfide colloid 림프스캔을 이용하 여 복수가 없으며 저단백혈증, 저알부민혈증이 더 심한 군에서 장관내 방사성 물질을 흔하게 관찰할 수 있음을 보고하여 임상적 응용 가능 성을 보여주었다. 이번 증례에서는 인혈청알부민이 현재는 상품화되 지 않아 ${ }^{99 m} \mathrm{Tc}-$ phytate 림프스캔을 시행하였으며 복수와 경한 저알부 민혈증을 보인 환자로 림프스캔에서 장관 내로 동위원소의 축적이 관 찰되지 않았다.

위의 방법 이외에도 복부 초음파, 복부 컴퓨터단층촬영, 상부위장 관조영술, 소장조영술 등이 진단에 이용되기도 하는데 이것들은 주로 이차적인 원인들을 제외시키는 데 도움을 준다. 최근에는 장림프관확 장증의 진단 및 이환된 범위를 평가하는 데 캡슐내시경도 의의가 있 는 것으로 보고되고 있다. ${ }^{12}$ 비교적 안전하고 쉬운 캡슐내시경은 소장 질환 진단의 첫 번째 검사이며, 이중풍선 소장내시경은 캡슐내시경 이 후 생검이나 치료시술이 필요한 병변, 그리고 캡슐내시경에서 병변이 관찰되지 않지만 소장질환이 강력히 의심될 때 시행하는 것으로 그 공감대가 형성되었다. 이번 증례에서는 국내 의료여건에서 고가의 두 검사 시행이 쉽지 않으며, 소장질환의 양성병변에 대한 진단율이 이중 풍선 소장내시경에서 약간 높고, 소장 조직검사는 다른 질환과 감별 하는 데 매우 민감한 진단방법으로 치료 결정에 미치는 영향이 큰 것 으로 알려져 있어 이중풍선 소장내시경을 우선적으로 시행하였다. ${ }^{13}$ 전신부종, 저알부민혈증, 저단백혈증을 호소하는 환자에서 다른 검사 로는 원인을 알 수 없었던 경우로, 소장조영술에서 소장점막 주름 비 대와 복부 컴퓨터단층촬영에서 소장 전체에 걸쳐 분포가 확인되었으 며 이중풍선 소장내시경을 실시하여 십이지장 제 3 부, 공장, 회장 점 막부에 다발성 결절성 백색 반점 소견과 조직검사시 우윳빛의 분비물 이 스며 나왔고, 점막층에서 림프관확장이 관찰되어 장림프관확장증 을 확진한 증례이다.

이 질환의 치료는 식이요법이 일차적 치료인데, 식사 내 지방 성분 이 장림프계에 과부하를 일으켜 국소 림프관의 압력 증가로 유미의 장내 유출을 가져오므로 ${ }^{6}$ 저지방, 고단백 식이가 필요하며, 지방의 보 충은 림프관을 우회해서 문맥으로 흡수되는 중쇄 중성지방 섭취와 지용성 비타민을 공급하거나 칼슘, 마그네슘 같은 전해질 보충, 고영 양 수액법을 시행한다. 일부 보고에서는 국한된 원발장림프관확장증 이 보이는 경우 이환된 병변이 있는 장을 제거하는 치료 방법도 제시 되었지만, 보편화된 치료법은 아니다. ${ }^{6}$ 그러나 식이요법으로 호전되 지 않는 장림프관확장증 환자의 경우 항플라즈민 요법(antiplasmin therapy)이 위장질환에 의한 단백질소실장병증을 호전시켰다고 발표 하였으나, ${ }^{4}$ 일부에서는 항플라즈민 요법에도 별 반응이 없다고 보고 하여 아직 논란이 많다. ${ }^{15}$ 최근 여러 연구에 의해 octreotide를 투여해 서 임상 증상 및 검사소견의 호전을 본 경우도 있으나 이 경우 약을 중
지하면 다시 증상이 악화되므로 약을 지속적으로 사용해야 하는 한 계점이 있다. ${ }^{15} .16$ 이차적인 원인에 의한 장림프관확장증의 치료로 스 테로이드와 헤파린의 치료가 효과적이라는 보고는 있으나 식이요법 이 듣지 않은 경우에는 적절한 치료가 없는 실정이며 이 경우 예후가 나쁘다. 식이요법과 약물요법에 반응하지 않는 장림프관확장증 환자 에서 현재의 치료에 대한 장기간 사용에 대한 연구와 림프관 발생과 정의 기형 원인, 단백질소실의 기전, 널리 이용되며 구입하기 쉬운 진 단 방법에 대한 연구가 필요하겠다.

저자들은 전신부종, 복부팽만을 주소로 내원한 54세 남자환자에 서 대변 alpha 1-antitrypsin 청소율을 통해 위장관을 통한 단백질소 실을 증명하였고, 이중풍선 소장내시경을 이용한 조직검사를 통해 비 정상적으로 확장된 림프관을 확인하여 원발장림프관확장증을 진단 하였기에 문헌고찰과 함께 보고하는 바이다.

\section{REFERENCES}

1. Gordon RS Jr. Exudative enteropathy: abnormal permeability of the gastrointestinal tract demonstrable with labelled polyvinylpyrrolidone. Lancet 1959;1:325-326.

2. Waldmann TA, Steinfeld JL, Dutcher TF, Davidson JD, Gordon RS Jr. The role of the gastrointestinal system in "idiopathic hypoproteinemia”. Gastroenterology 1961;41:197-207.

3. Lim PJ, Park JO, Lee DH, Shin SM, Kim DW. A case of congenital intestinal lymphangiectasia. J Korean Pediatr Soc 1998;41:12931298.

4. Kwon WH, Hwang JB, Lee YH, Kim YJ. Endoscopic diagnosis of primary intestinal lymphangiectasia using a high-fat meal in a 20-month-old boy. Korean J Pediatr Gastroenterol Nutr 1999;2:93-98.

5. Chinnock BF. Chylothorax: case report and review of the literature. J Emerg Med 2003;24:259-262.

6. Lee SH, Chang YW, Bak SK, et al. A case of duodenal lymphangiectasia. Korean J Gastroenterol 2003;41:59-63.

7. Yim HE, Jung MJ, Yoo KH, Hong YS, Lee JW, Kim SK. A case of intestinal lymphangiectasia. J Korean Pediatr Soc 2003;46:921925.

8. Ryu JK, Kim JW, Koh KC, et al. Intestinal $\alpha 1$-antitrypsin clearance in normal subjects and in patients with gastrointestinal disorders. Korean J Gastroenterol 1993;25:287-294.

9. Strygler B, Nicar MJ, Santangelo WC, Porter JL, Fordtran JS. Alpha 1-antitrypsin excretion in stool in normal subjects and in patients with gastrointestinal disorders. Gastroenterology 1990;99:1380-1387.

10. Ko JS, Seo JK. Significance of endoscopic small bowel biopsy in the diagnosis of intestinal lymphangiectasia in children. Korean J Gastrointest Endosc 1997;17:760-767.

11. So Y, Chung JK, Seo JK, et al. Different patterns of lymphoscintigraphic findings in patients with intestinal lymphangiectasia. Nucl Med Commun 2001;22:1249-1254.

12. Chamouard P, Nehme-Schuster H, Simler JM, Finck G, Baumann R, Pasquali JL. Videocapsule endoscopy is useful for the diagnosis of intestinal lymphangiectasia. Dig Liver Dis 2006;38:699- 
703.

13. Takenaka H, Ohmiya N, Hirooka Y, et al. Endoscopic and imaging findings in protein-losing enteropathy. J Clin Gastroenterol 2012;46:575-580.

14. Kondo M, Bamba T, Hosokawa K, Hosoda S, Kawai K, Masuda $\mathrm{M}$. Tissue plasminogen activator in the pathogenesis of proteinlosing gastroenteropathy. Gastroenterology 1976;70:1045-1047.
15. Bac DJ, Van Hagen PM, Postema PT, ten Bokum AM, Zondervan PE, van Blankenstein M. Octreotide for protein-losing enteropathy with intestinal lymphangiectasia. Lancet 1995;345:1639.

16. Kuroiwa G, Takayama T, Sato Y, et al. Primary intestinal lymphangiectasia successfully treated with octreotide. J Gastroenterol 2001;36:129-132. 